\title{
SELECTION AND POPULATION STRUCTURE IN LOLIUM
}

\section{CONTINUED RESPONSE AND ASSOCIATED CHANGES IN FERTILITY AND VIGOUR}

\author{
J. P. COOPER \\ Welsh Plant Breeding Station, Aberystwyth
}

\section{INTRODUCTION}

Received 20.iv.6r

EARLIER papers (Cooper, I959 $a, b, c$; I960) have described the first three generations of response to selection for date of ear emergence in Irish and Kent perennial ryegrass (Lolium perenne L.). This character shows high heritability ( $>70$ per cent.), most of the variation being genetic and additive. Rapid immediate response to selection occurred in both varieties, and by the third generation the extreme selection lines were well outside the parental range. Furthermore, most plants are highly heterozygous, and even one plant can carry considerable potential genetic variation.

Two further aspects which required investigation, (i) the pattern of response to continued selection over several generations and (ii) the effect of selection for ear emergence on other characters, particularly fertility and vigour, are dealt with in this paper.

\section{MATERIAL AND METHODS}

The foundation populations consisted of Irish and Kent perennial ryegrass from commercial stocks. Irish is an early-flowering variety which has been grown for seed production for many generations, while Kent is a late-flowering pasture variety, with little agronomic selection for either seed production or uniformity of heading (Cooper, 1959a). Ear emergence occurs in Irish about the beginning of May, and in Kent some 20-25 days later, but the exact date is greatly influenced by spring temperature, and year to year fluctuations of up to 14 days may occur (table 1). The phenotypic variance is usually greater in Kent than in Irish.

Operational details of the selection programme have been given by Cooper (1959c). During the first three generations, early and late selection lines based on one, two and four foundation plants were derived from each variety. Back-selection was started in the first generation to assess the amount of potential genetic variation carried within each initial group of plants. After the third generation, the lines derived from one and two initial plants showed pronounced inbreeding depression, and only the four-plant lines were continued.

Male and female fertility were measured in summer 1960 on the original varieties and the sixth generation selection lines. Male fertility was assessed from the percentage of pollen stainable with aceto-carmine. Anthers were fixed in 70 per cent. alcohol just before anthesis, and counts were made on anthers from three heads on each plant to give an estimate of within-plant variation. Pollen stainability does not strictly measure the viability of the pollen, but it does provide an upper limit for fertility. Female fertility was measured as the percentage seed-set from openpollination in the field. The selection experiment was sited in the middle of the plant breeding nursery, so that availability of pollen was not likely to have been 
limiting. Three heads were taken from each plant to provide a measure of withinplant variation.

Since the selection programme involves a moderate degree of inbreeding, which may itself have an effect on fertility and vigour, an attempt was made to determine the actual level in the selection lines by comparison with families of known degrees of inbreeding. The original varieties and the first five generations of selection were

TABLE 1

Date of ear emergence in the original varieties

\begin{tabular}{|c|c|c|c|c|}
\hline \multirow{2}{*}{ Year } & \multicolumn{2}{|c|}{ Irish } & \multicolumn{2}{|c|}{ Kent } \\
\hline & Mean & Var. & Mean & Var. \\
\hline $\begin{array}{l}1954 \\
1955 \\
1956 \\
1957 \\
1958 \\
1959 \\
1960\end{array}$ & $\begin{array}{l}3.4 \text { May } \\
14.0 \% " \\
8 \cdot 7 \text { " } \\
30 \cdot 4 \text { April } \\
8 \cdot 3 \text { May } \\
30 \cdot 1 \text { April } \\
30 \cdot 0 \quad "\end{array}$ & $\begin{array}{l}24 \cdot 0 \\
30 \cdot 7 \\
12.4 \\
18 \cdot 7 \\
17 \cdot 5 \\
27 \cdot 8 \\
17.0\end{array}$ & $\begin{array}{ll}24 \cdot 1 & \text { May } \\
29 \cdot 7 \quad ", \\
22 \cdot 5 \quad " \\
22 \cdot 8 \quad, \\
28 \cdot 2 \quad, \\
21 \cdot 5 \quad, \\
23 \cdot 5 \quad,\end{array}$ & $\begin{array}{l}26 \cdot 4 \\
24 \cdot 5 \\
18 \cdot 0 \\
40 \cdot 0 \\
25 \cdot 3 \\
17 \cdot 5 \\
41.4\end{array}$ \\
\hline Mean & 5.0 May & $21 \cdot 2$ & $24 \cdot 6$ May & $27 \cdot 6$ \\
\hline
\end{tabular}

sown in a warm glasshouse in January 1960 , together with several sib-crosses and selfed progenies of Irish and Kent ryegrass. The following seedling measurements were taken :

(i) leaf size, measured as length $\times$ median width of the sixth leaf on the main shoot

(ii) rate of leaf appearance, from the $4^{\text {th }}$ to the $7^{\text {th }}$ leaf on the main shoot

(iii) tiller number, dry weight per plant and per tiller measured 78 days after sowing.

The genetic control and inter-relationship of these seedling characters have been described elsewhere (Cooper and Edwards, 196r).

\section{RESPONSE TO SELECTION}

(i) Change in means

The pattern of response to selection is shown in fig. I where the cumulative response for each generation is plotted against the cumulative selection differentials, as suggested by Falconer (1955). The numerical values for selection differentials, response and realised heritabilities are given in table 2. The release of variation from within each of the initial four-plant groups is shown in fig. 2, and the total range achieved in table 3 . The response in each generation has been measured as the difference between the mean of the selection line and that of the original variety in the same year.

Response has continued at a linear rate in most of the forward lines. The extreme lines are now well outside the limits of the original varieties and the full range of Irish has been obtained from Kent, and 
vice versa. Although the selection differential is similar in both directions, the response, and, therefore, the realised heritability, are asymmetrical, being always greater in the late direction. Both the selection differential and the heritability are greater for corresponding lines in

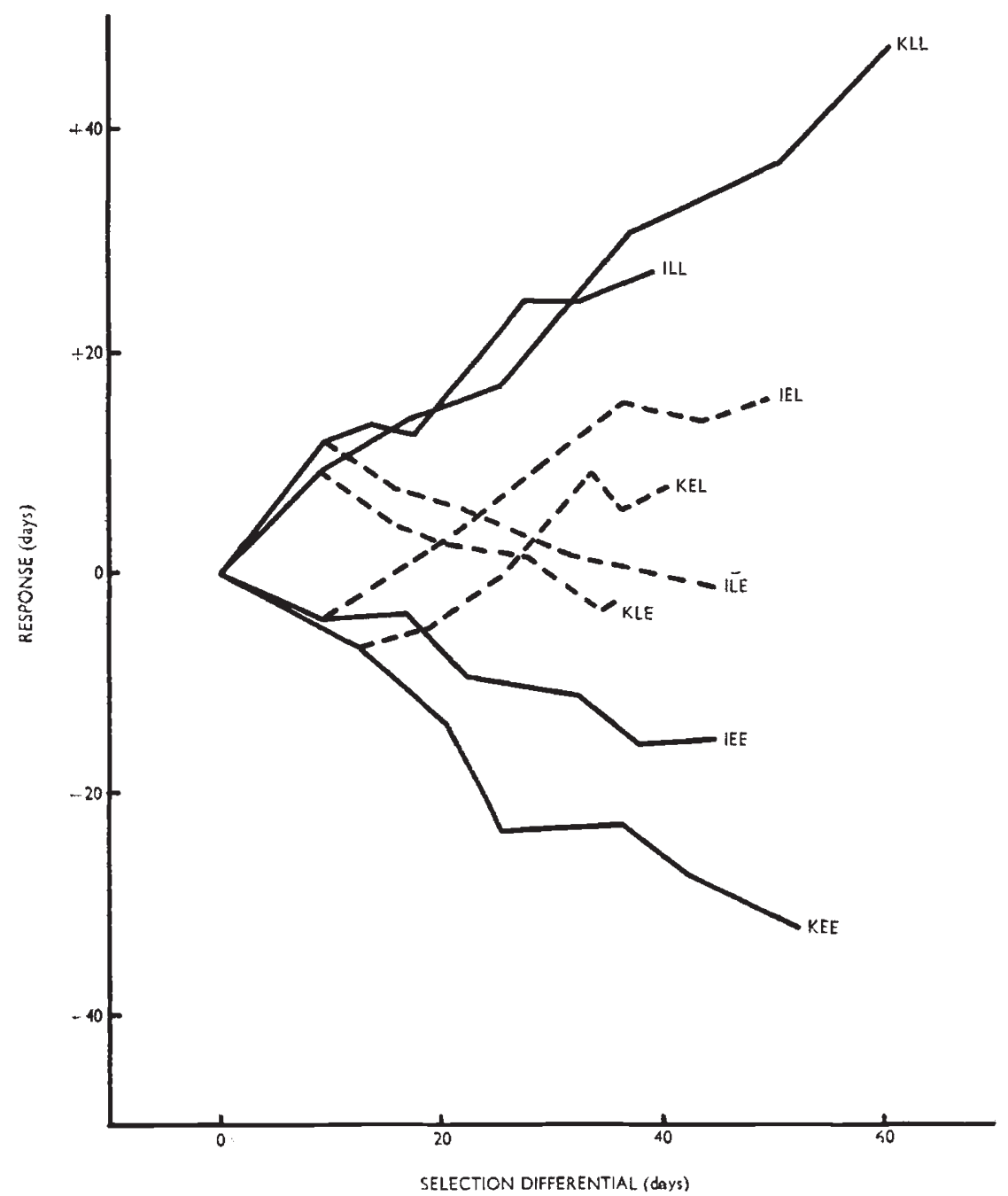

Frc. 1.- Response to selection for early and late ear emergence. Irish and Kent perennial

$$
\begin{aligned}
& \mathrm{KEE}=\text { Kent early-early } \\
& \mathrm{KEL}=\text {, } \text { early-late } \\
& \mathrm{KLE}=\text {, late-early } \\
& \mathrm{KLL}=\text { " late-late }
\end{aligned}
$$

$$
\text { ryegrass. }
$$

$$
\begin{aligned}
& \text { IEE }=\text { Irish early-early } \\
& \text { IEL }=" \text { early-late } \\
& \text { ILE }=", \text { late-early } \\
& \text { ILL }=" \text { late-late. }
\end{aligned}
$$

Kent than in Irish, possibly as a result of less stringent agronomir selection in the past. The realised heritabilities are quite high (3070 per cent.) and there is no marked evidence as yet of any ceiling of response having been reached, except perhaps for the earliest line 
(IEE). Even so, the realised heritabilities are below the estimates obtained from parent-progeny regression in one year, particularly in the early lines. This may be due partly to genotype-environment

TABLE 2

Selection differentials and realised heritabilities in the selection lines

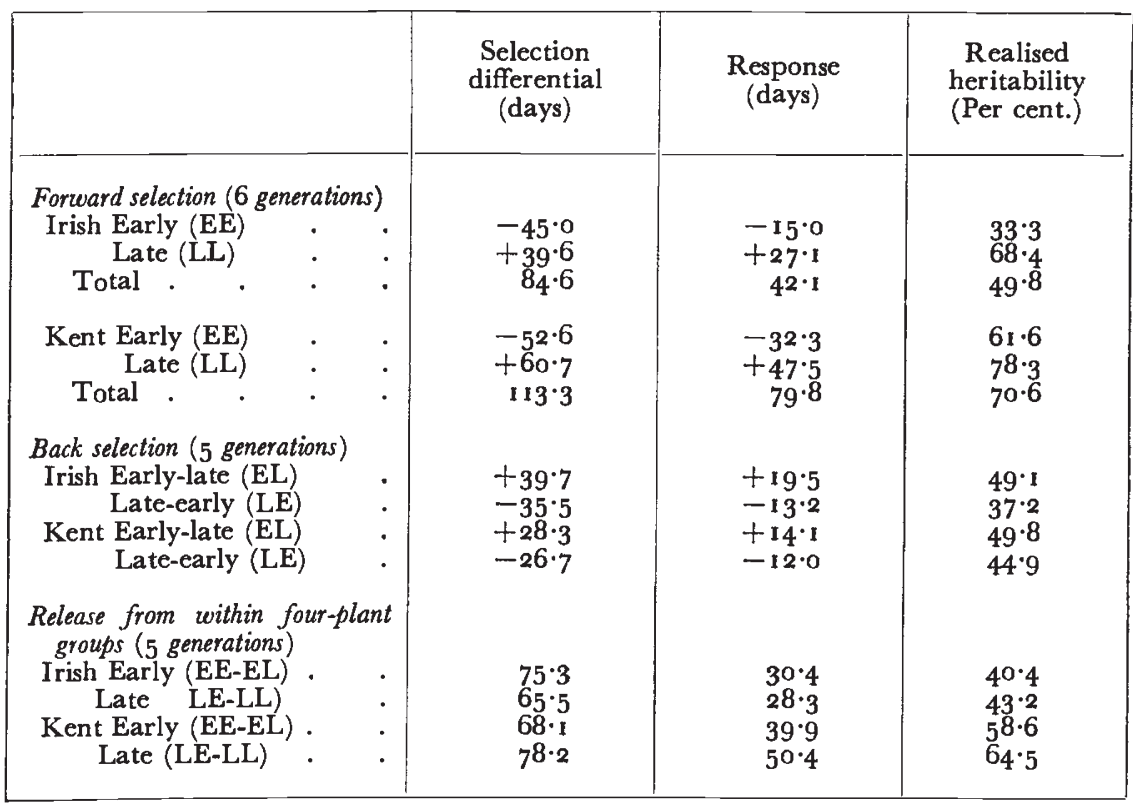

TABLE 3

Phenotypic range in the original varieties and sixth generation selection lines

\begin{tabular}{|c|c|c|c|c|}
\hline \multicolumn{3}{|c|}{ Original variety } & \multicolumn{2}{|c|}{ Six generation selection lines } \\
\hline Mean & & Range & $\begin{array}{l}\text { Range between } \\
\text { means }\end{array}$ & $\begin{array}{l}\text { Range between } \\
\text { extreme plants }\end{array}$ \\
\hline $\begin{array}{l}\text { Irish } \\
\quad 30 \cdot 0 \text { April }\end{array}$ & • & $\begin{array}{l}17 \text { April-1 I May } \\
\text { (24 days) }\end{array}$ & $\begin{array}{c}15.8 \text { April-27.9 May } \\
(42 \cdot 1 \text { days })\end{array}$ & $28 \underset{\text { March-9 June }}{\text { (73 days })}$ \\
\hline $\begin{array}{l}\text { Kent } \\
23.5 \text { May }\end{array}$ & • & $\begin{array}{l}8 \text { May-6 June } \\
\text { (29 days) }\end{array}$ & $21 \cdot 2 \underset{(79 \cdot 8 \text { days })}{\text { April-10.0 July } *}$ & $7 \underset{\text { April-6 Aug.* }}{(121 \text { days) }}$ \\
\hline
\end{tabular}

* Omitting 3 non-flowering plants.

interaction from year to year, and partly, as will be discussed later, to inbreeding depression in the late lines resulting in asymmetrical response.

In general, the response in the back-selection lines has not been so great as in the forward lines, and in two lines (KEL and KLE) low 
fertility has severely decreased the possible selection differential in the later generations. Even so, the release of variation from within four initial plants of the same phenotype has been considerable (table 2 ; fig. 2), and the early and late lines from the same initial group are by now completely discontinuous. The release of variation is again less

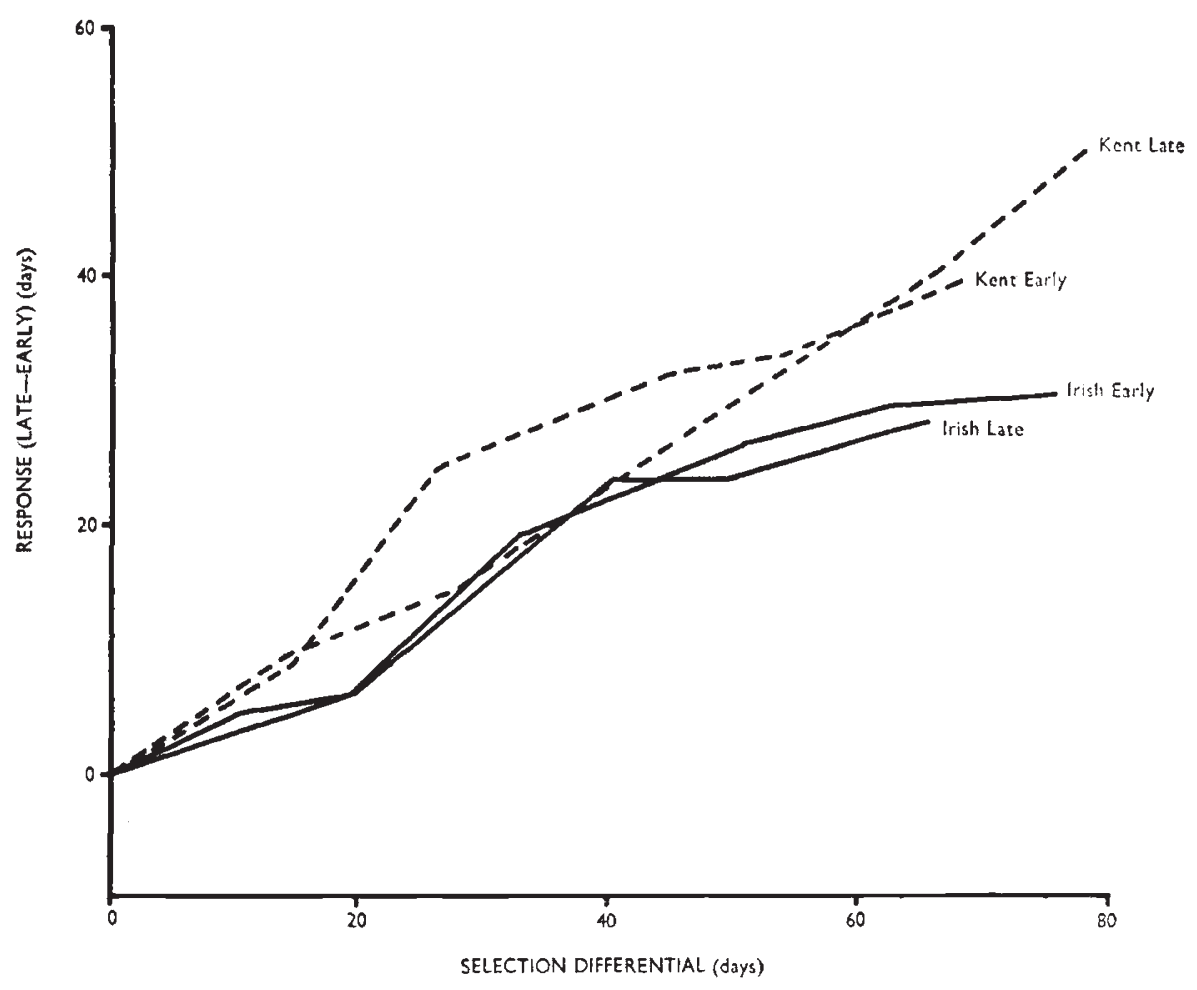

Fig. 2.-Release of variation from foundation groups of four plants.

in Irish than in Kent, but there is no regular difference between the early and late foundation groups.

\section{(ii) Change in variances}

The changes in phenotypic variance within the lines during the course of selection are shown in table 4 , which also gives the withingenotype variance derived from clonal replicates in each generation. In the original varieties, Kent usually shows a higher phenotypic variance than Irish. In the first generation the variance decreases as expected, since it is based on pair-crosses with strict assortative mating for date of ear emergence. There is no regular change in subsequent generations, and the average within-line variance in the sixth generation approaches that of the original varieties. There are, however, marked differences between lines, and by the sixth generation the backselection lines are usually more uniform than the forward lines. This is 
particularly marked in lines IEL and KEL, and the possible selection differential is correspondingly reduced (fig. I).

In spite of the selection and inbreeding there has been no regular change in the developmental error within clones. A surprisingly high

TABLE 4

Changes in variance for date of ear emergence under selection

\begin{tabular}{|c|c|c|c|c|c|c|c|c|}
\hline & & \multicolumn{6}{|c|}{ Original varieties } & \multirow{2}{*}{ Mean } \\
\hline & & 1955 & 1956 & 1957 & $195^{8}$ & г959 & 1960 & \\
\hline \multirow[t]{3}{*}{$\begin{array}{l}\text { Irish } \\
\text { Kent }\end{array}$} & \multirow[t]{3}{*}{ : } & $\begin{array}{l}30 \cdot 7 \\
24 \cdot 5\end{array}$ & $\begin{array}{l}12 \cdot 4 \\
18 \cdot 0\end{array}$ & $\begin{array}{l}18 \cdot 7 \\
40 \cdot 0\end{array}$ & $\begin{array}{l}17 \cdot 5 \\
25 \cdot 3\end{array}$ & $\begin{array}{l}27.8 \\
17.5\end{array}$ & $\begin{array}{l}17 \cdot 0 \\
41 \cdot 4\end{array}$ & $\begin{array}{l}20.7 \\
27.8\end{array}$ \\
\hline & & \multicolumn{6}{|c|}{ Generations of selection } & \\
\hline & & $\begin{array}{c}\text { Ist } \\
(1955)\end{array}$ & $\begin{array}{l}\text { 2nd } \\
(1956)\end{array}$ & $\begin{array}{c}3^{\text {rd }} \\
(1957)\end{array}$ & $4^{4^{\text {th }}}$ & $5^{5^{\text {th }}}$ & $\begin{array}{l}\text { 6th } \\
(1960)\end{array}$ & \\
\hline $\begin{array}{c}\text { Irish } \\
\text { EE } \\
\text { EL }\end{array}$ & . & $19 \cdot 8$ & $\left\{\begin{array}{l}13 \cdot 2 \\
17 \cdot 2\end{array}\right.$ & $\begin{array}{l}21 \cdot 9 \\
29 \cdot 7\end{array}$ & $\begin{array}{l}12 \cdot 1 \\
33.3\end{array}$ & $\begin{array}{r}19 \cdot 9 \\
8 \cdot 3\end{array}$ & $\begin{array}{r}6 \mathrm{x} \cdot 6 \\
7 \cdot 8\end{array}$ & \\
\hline $\begin{array}{l}\text { LE } \\
\text { LL }\end{array}$ & $\dot{.}$ & $7 \cdot 4$ & $\left\{\begin{array}{r}13.3 \\
9.8\end{array}\right.$ & $\begin{array}{r}15.8 \\
18.8\end{array}$ & $\begin{array}{r}12 \cdot 1 \\
7 \cdot 8\end{array}$ & $\begin{array}{l}24 \cdot I \\
16 \cdot 4\end{array}$ & $\begin{array}{l}12 \cdot 3 \\
30 \cdot 7\end{array}$ & \\
\hline Mean & . & $13 \cdot 6$ & $13 \cdot 4$ & $21 \cdot 6$ & $16 \cdot 3$ & $17 \cdot 2$ & $28 \cdot 1$ & \\
\hline $\begin{array}{c}\text { Kent } \\
\mathrm{EE} \\
\mathrm{EL}\end{array}$ & $\dot{.}$ & 15.5 & $\left\{\begin{array}{l}10 \cdot 2 \\
14 \cdot 5\end{array}\right.$ & $\begin{array}{l}24 \cdot 2 \\
12 \cdot 3\end{array}$ & $\begin{array}{l}13 \cdot 2 \\
25 \cdot 1\end{array}$ & $\begin{array}{r}32 \cdot 8 \\
5 \cdot 0\end{array}$ & $\begin{array}{r}50 \cdot 8 \\
7 \cdot 5\end{array}$ & \\
\hline $\begin{array}{l}\mathrm{LE} \\
\mathrm{LL}\end{array}$ & $\dot{.}$ & $16 \cdot 4$ & $\left\{\begin{array}{l}12 \cdot 1 \\
33 \cdot 2\end{array}\right.$ & $\begin{array}{l}15 \cdot 7 \\
10 \cdot 0\end{array}$ & $\begin{array}{l}13 \cdot 7 \\
44 \cdot 9\end{array}$ & $\begin{array}{l}15.5 \\
18.0\end{array}$ & $\begin{array}{c}13 \cdot 3 \\
(123 \cdot 7)^{*}\end{array}$ & \\
\hline Mean & . & $16 \cdot 0$ & $17 \cdot 5$ & $15 \cdot 6$ & $24 \cdot 2$ & $17 \cdot 8$ & $23 \cdot 9$ & \\
\hline \multicolumn{2}{|c|}{ Developmental error } & & & & & & & \\
\hline $\begin{array}{l}\text { Irish } \\
\text { Kent }\end{array}$ & $: \quad:$ & $\begin{array}{l}1 \cdot 7 \\
1 \cdot 7\end{array}$ & $\begin{array}{l}2 \cdot 7 \\
4 \cdot 0\end{array}$ & $\begin{array}{l}1 \cdot 4 \\
2 \cdot 9\end{array}$ & $\begin{array}{l}5 \cdot 3 \\
7 \cdot 1\end{array}$ & $\begin{array}{l}4 \cdot 8 \\
1 \cdot 6\end{array}$ & $\begin{array}{l}\cdots \\
\cdots\end{array}$ & \\
\hline \multicolumn{2}{|c|}{$\begin{array}{l}\text { Mean coeff. of } \\
\text { inbreeding }\end{array}$} & o & $0 \cdot 125$ & 0.219 & 0.305 & $0 \cdot 381$ & 0.449 & \\
\hline
\end{tabular}

* Three plants failed to head. This variance, based on heading plants only, not included in mean.

figure is recorded for both Irish and Kent in the fourth generation, but this is not continued in later generations. Thus, there appears to be no regular decline in genotypic variation within the lines, in spite of the expected effect of selection in concentrating genes for early and late ear emergence, and the moderate inbreeding practised, which gives a theoretical inbreeding coefficient of $0 \cdot 45$ by the sixth generation. 


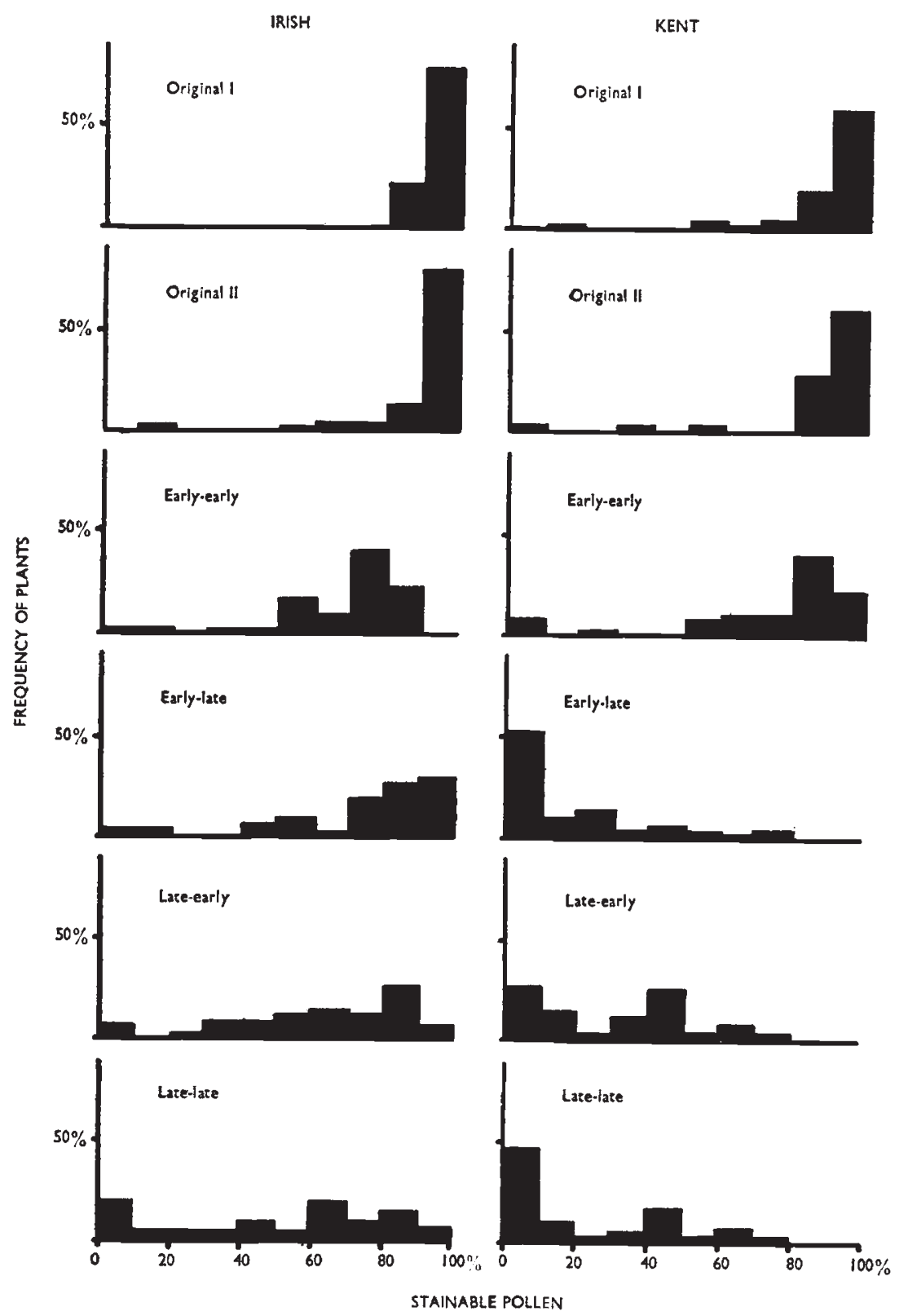

Fig. 3.-Male fertility in original varieties and sixth generation selection lines.

\section{CHANGES IN FERTILITY}

The male and female fertility in the original varieties and in the sixth generation lines are shown in figs. 3 and 4 and the betweenand within-plant variances are given in table 5. All fertility data were transformed to degrees for statistical analysis. 


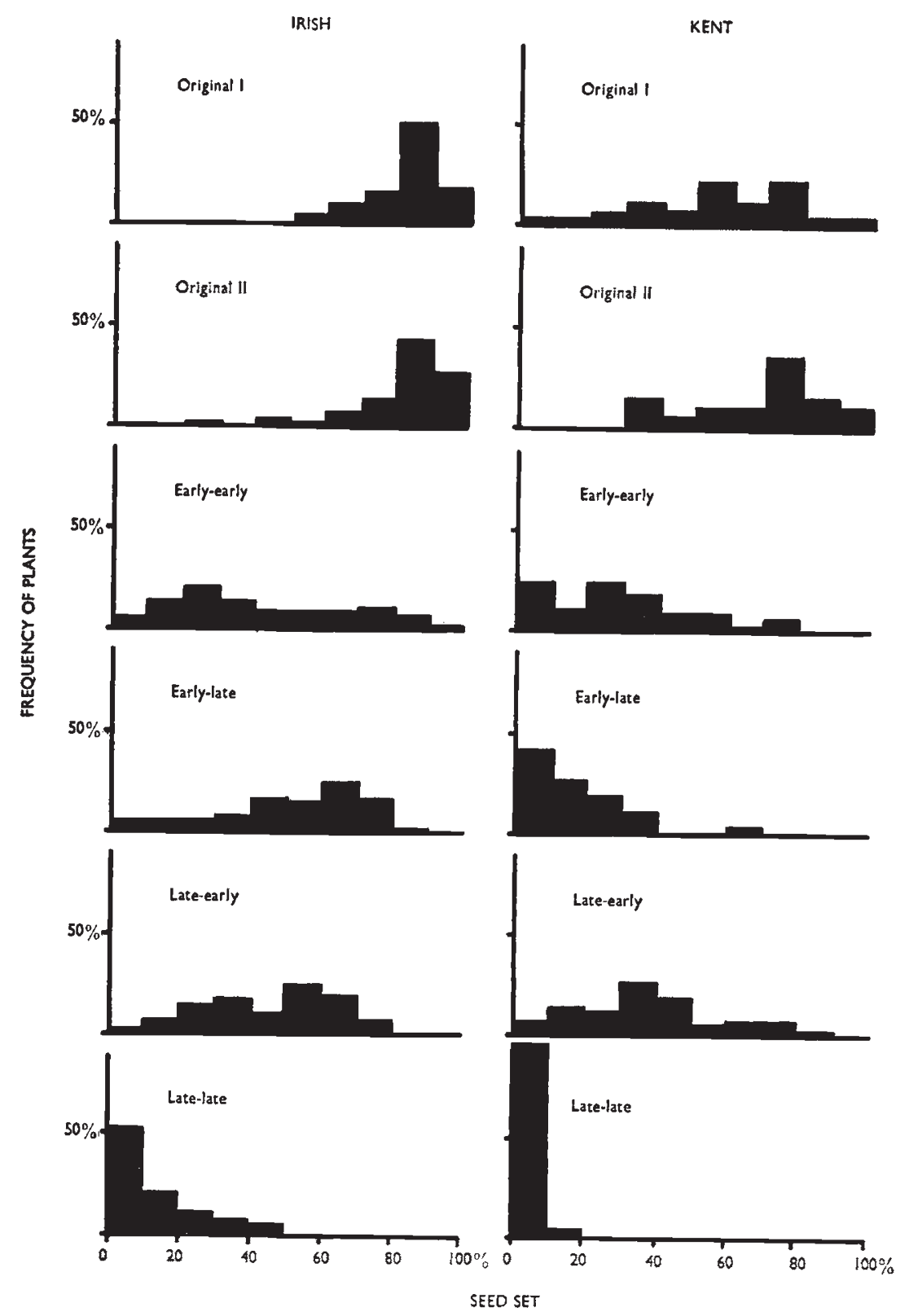

Frg. 4.-Female fertility in original varieties and sixth generation selection lines.

The pollen fertility in the two samples of each original variety was high, being over 90 per cent. in most plants. Kent, however, has a lower mean and greater variance than Irish, with a marked tail of plants of low fertility. The within-plant variance is also higher in Kent than in Irish. 
All the selection lines show a reduction in pollen fertility, with an increased variance, though the early lines are usually more fertile than the late, possibly due to a lower degree of inbreeding. There is little difference between Irish and Kent for corresponding forward selection lines, but the back selection lines KEL and KLE are very low (12 per cent. and 15 per cent.). These low pollen fertilities result

TABLE 5

Male and female fertility in the selection lines

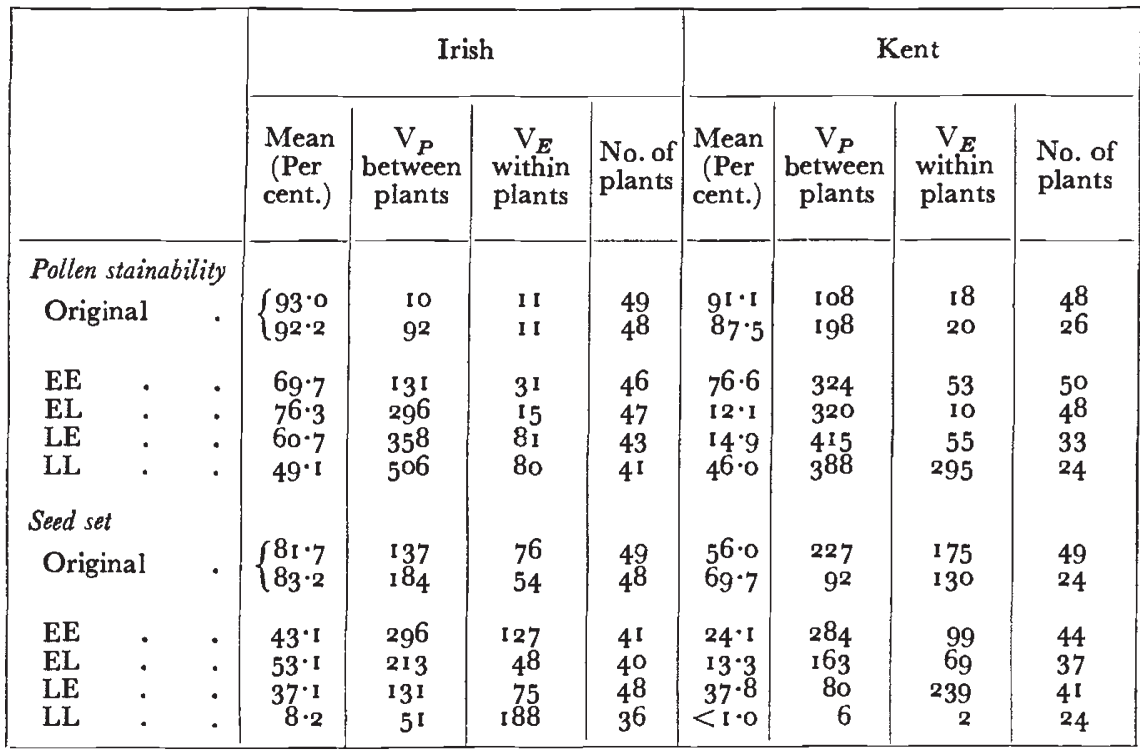

NoTE.-All variances based on data transformed to degrees

\begin{tabular}{|c|c|c|c|c|}
\hline \multirow{2}{*}{ Sample analysis } & \multicolumn{4}{|c|}{ Pollen stainability (IEE) } \\
\hline & $d F$ & SS & MS & Expectation \\
\hline $\begin{array}{l}\text { Between plants } \\
\text { Within plants }\end{array}$ & $\begin{array}{l}45 \\
89\end{array}$ & $\begin{array}{r}19,124 \\
2,727\end{array}$ & $\begin{array}{r}425 \\
31\end{array}$ & $\mathrm{~V}_{E}+\mathrm{V}_{E} \mathrm{~V}_{P}$ \\
\hline Total . & 134 & $21,8_{51}$ & & \\
\hline
\end{tabular}

in non-dehiscent anthers and, therefore, functional male sterility in many plants, but are not accompanied by a corresponding decrease in female fertility. The within-plant variance is increased in most of the selection lines.

Female fertility presents a similar picture though the figures are lower than for pollen fertility (except for the male-sterile lines KEL and KLE). The seed-set for the original Irish is high, usually over 80 per cent., but in Kent the mean is lower ( $50-70$ per cent.) with a 
larger variance, suggesting less stringent agronomic selection in the past. All the selection lines show a much lower seed-set than do the original varieties, and this is most marked in the late lines (ILL and KLL). In KLL, which is very late flowering, this may result from lack of available pollen, but for ILL ample pollen was present. The Kent lines again usually show a lower seed-set than the corresponding ones from Irish and, in the forward selection, the early lines are usually more fertile than the late.

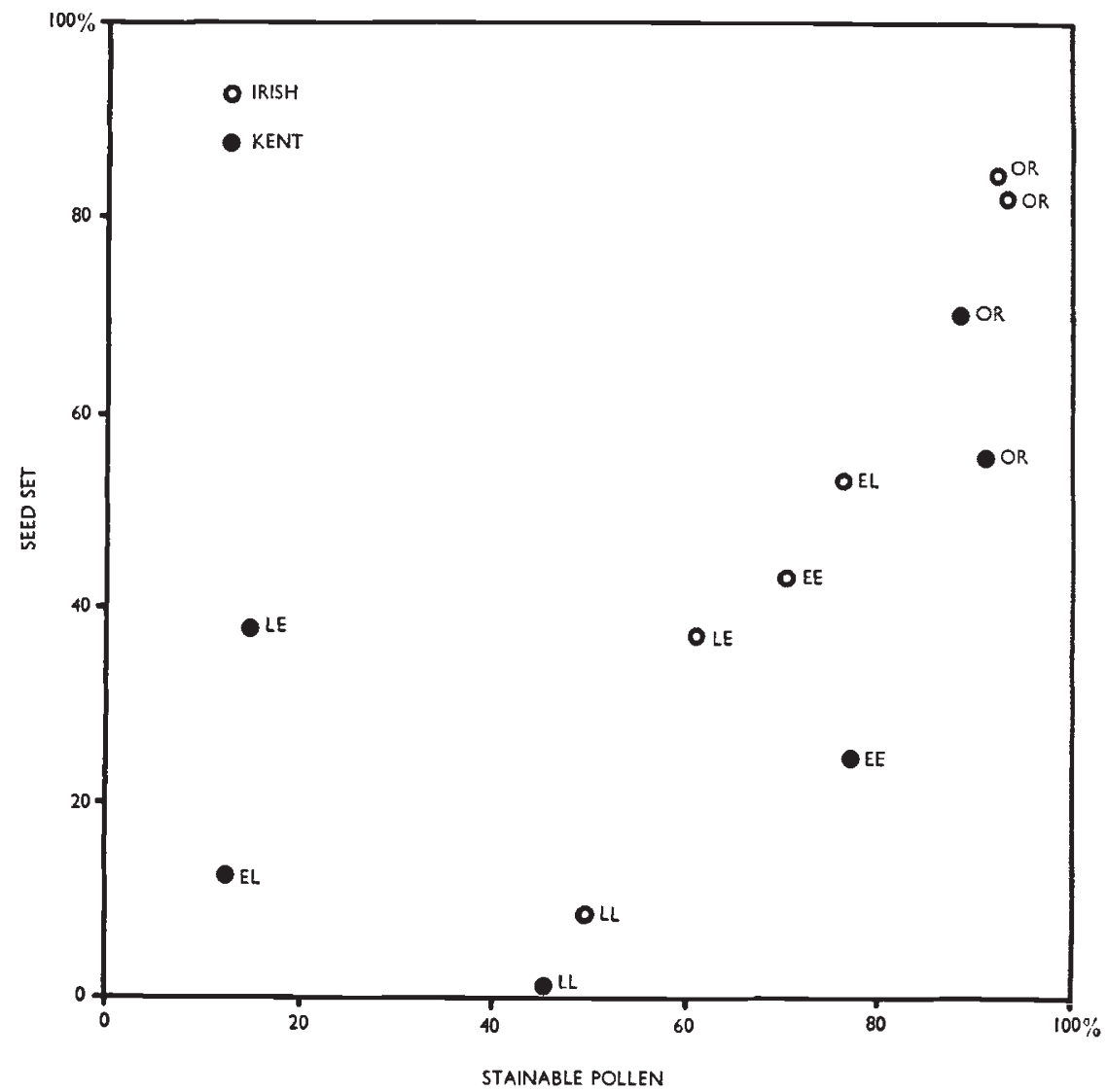

FIG. 5.-Correlation between mean male and female fertility in original varieties and sixth generation selection lines.

There is a good correlation between mean seed-set and pollen stainability for the original varieties and the selection lines (fig. 5), with the exception of KEL and KLE, which were noted as early as the third generation to show poor pollen fertility and a high proportion of non-dehiscent anthers. The reduction in seed-set is greater than that in pollen fertility, but the two are roughly proportional, which suggests a similar mechanism operating in the two sexes.

The correlation of male and female fertility within the lines, however, is more complex (fig. 6). With high pollen fertilities above about 
$5^{\circ}$ per cent., there appears to be no correlation with female fertility, but when the pollen stainability falls below $5^{\circ}$ per cent. a marked correlation with seed-set becomes apparent, and very low pollen fertilities are usually accompanied by low seed-sets. This correlated
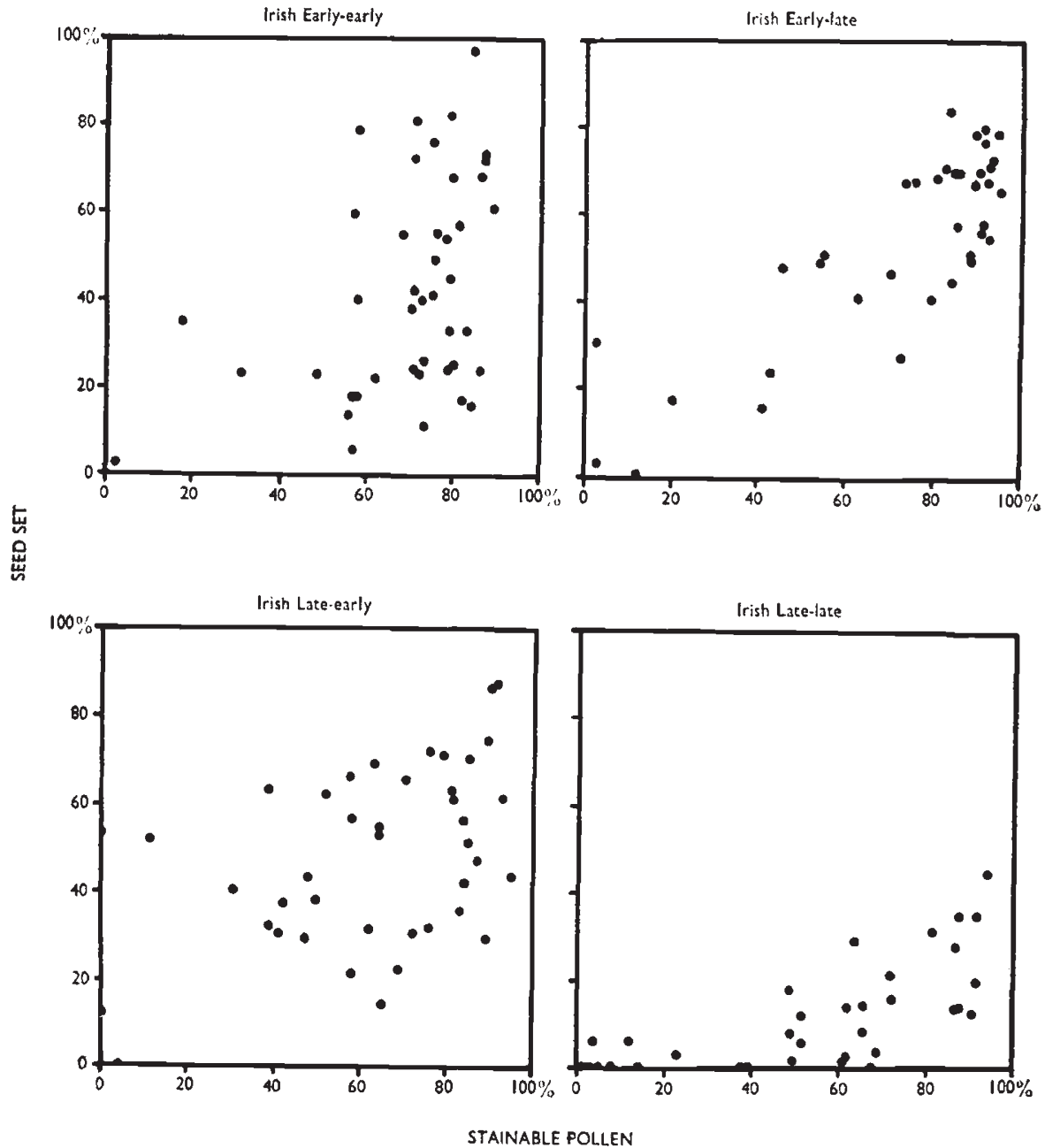

FIG. 6.-Correlation between male and female fertility within selection lines of Irish perennial ryegrass.

effect on seed-set is not a result of shortage of pollen, as seed fertility was assessed from open-pollination in the breeding nursery.

The decreased fertility obtained as a result of selection for early and late ear emergence suggests that the extremely early and late plants within each line might be obviously less fertile. The correlation diagrams of male and female fertility against date of ear emergence were therefore plotted for the original varieties and the sixth generation selection lines, but, rather surprisingly, the association between 
fertility and the extremes of ear emergence was slight and within the late lines only (fig. 7).

The present selection programme for ear emergence evidently leads to a decline in both male and female fertility, but the relative
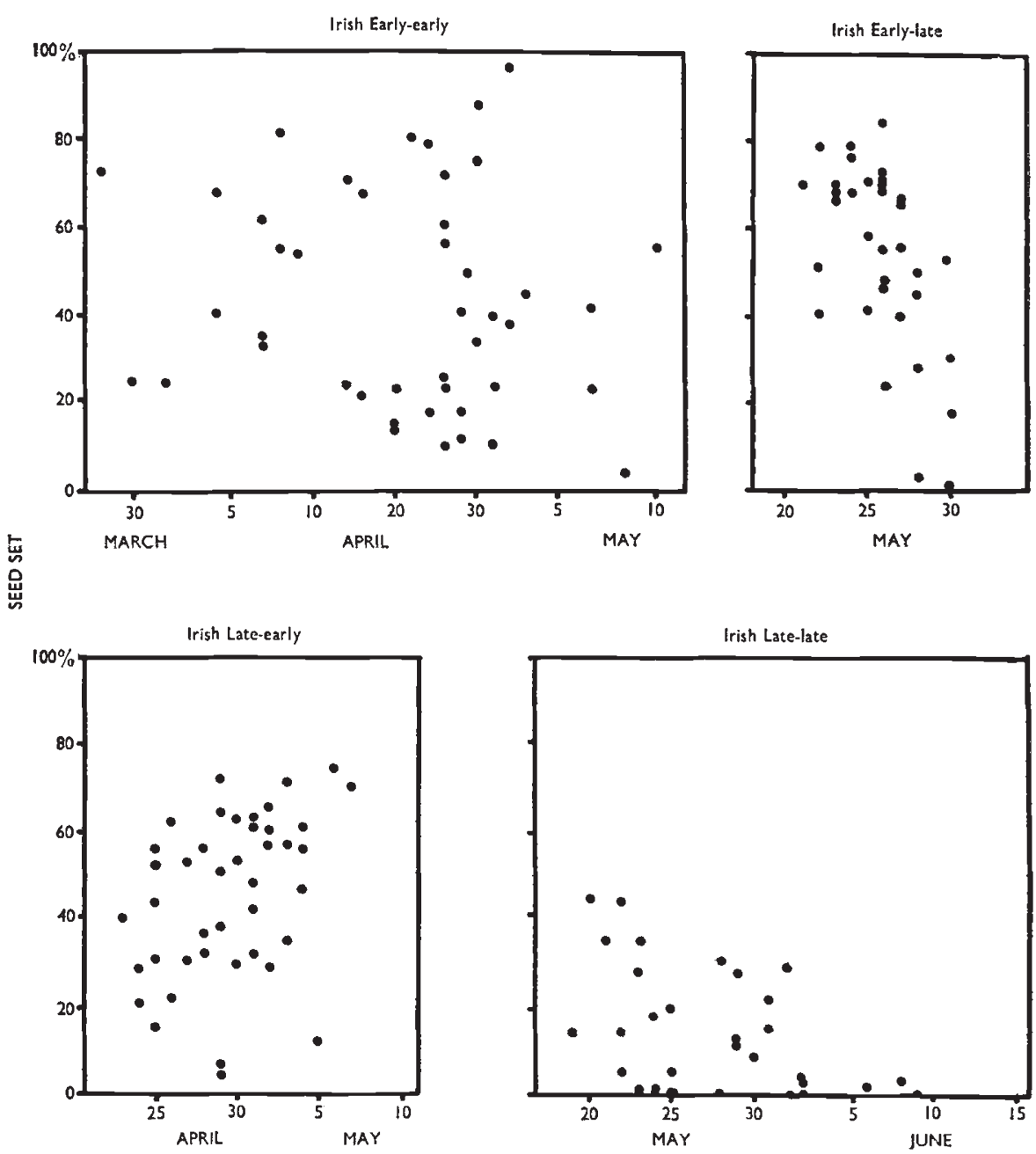

FiG. 7.-Correlation between female fertility and date of ear emergence within selection lines of Irish perennial ryegrass.

roles of selection and inbreeding in producing this effect are difficult to separate.

\section{SEEDLING CHARACTERS}

The seedling results should throw light on two important points: first, the extent of any correlated response to selection for ear emergence, and second, the actual degree of inbreeding reached in the selection lines. 
The seedling measurements for the original varieties and the fourth and fifth generation selection lines are given in table 6, while the behaviour of these characters under controlled inbreeding without selection is shown in table 7 .

TABLE 6

Correlated response and degree of inbreeding in seedling characters

\begin{tabular}{|c|c|c|c|c|c|c|c|c|}
\hline & \multicolumn{4}{|c|}{ Irish } & \multicolumn{3}{|c|}{ Kent* } & \multirow{3}{*}{$\begin{array}{c}\text { Sig. } \\
\text { diff. } \\
\text { between } \\
\text { means } \\
\text { at } \\
5 \text { per } \\
\text { cent. }\end{array}$} \\
\hline & \multirow{2}{*}{$\begin{array}{l}\text { Orig- } \\
\text { inal }\end{array}$} & \multicolumn{2}{|c|}{ Means } & \multirow{2}{*}{$\begin{array}{l}\text { Diff. } \\
\text { between } \\
\text { lines in } \\
5^{\text {th }} \text { gen. }\end{array}$} & \multirow{2}{*}{$\begin{array}{c}\text { Orig- } \\
\text { inal }\end{array}$} & \multicolumn{2}{|c|}{ Means } & \\
\hline & & $\begin{array}{l}4^{\text {th }} \\
\text { gen. }\end{array}$ & $\begin{array}{l}5^{\text {th }} \\
\text { gen. }\end{array}$ & & & $\begin{array}{l}4^{\text {th }} \\
\text { gen. }\end{array}$ & $\begin{array}{l}5^{\text {th }} \\
\text { gen. }\end{array}$ & \\
\hline Leaf size ( $\left.\mathrm{mm} .{ }^{2}\right)$ & ro 076 & 1071 & 1082 & $\mathrm{EL}>\mathrm{EE}$ & $84^{I}$ & $86 I$ & 832 & 97 \\
\hline $\begin{array}{l}\text { Rate of leaf } \\
\text { appearance } \\
\text { (days per leaf) }\end{array}$ & $7 \cdot 3$ & $7 \cdot 5$ & $8 \cdot 0$ & $\mathrm{EL}>\mathrm{EE}$ & $7 \cdot 0$ & $7 \cdot 1$ & $6 \cdot 9$ & 0.33 \\
\hline $\begin{array}{l}\text { Tiller No. } \\
\text { Dry weight per }\end{array}$ & $\begin{array}{l}18 \cdot 5 \\
0.55\end{array}$ & $\begin{array}{l}16.6 \\
0.49\end{array}$ & $\begin{array}{l}16 \cdot 0 \\
0 \cdot 44\end{array}$ & $\begin{array}{l}\mathrm{LE}>\mathrm{LL} \\
\text { None }\end{array}$ & $\begin{array}{l}17.3 \\
0.44\end{array}$ & $\begin{array}{l}13 \cdot 0 \\
0 \cdot 34\end{array}$ & $\begin{array}{c}12 \cdot 3 \\
0 \cdot 33\end{array}$ & $\begin{array}{l}2 \cdot 3 \\
0.08\end{array}$ \\
\hline plant (gm.) & & & & & & & & \\
\hline $\begin{array}{l}\text { Dry weight per } \\
\text { tiller (mgm.) }\end{array}$ & $3^{1}$ & 30 & 29 & None & 25 & 28 & 27 & $3 \cdot 5$ \\
\hline $\begin{array}{l}\text { Mean coefficient } \\
\text { of inbreeding }\end{array}$ & 0.0 & 0.305 & 0.381 & $\cdots$ & $0 \cdot 0$ & 0.305 & $0 \cdot 381$ & $\cdots$ \\
\hline
\end{tabular}

* No significant differences between pairs of selection lines for Kent in the $5^{\text {th }}$ generation.

TABLE 7

Effects of inbreeding without selection on seedling characters

\begin{tabular}{|c|c|c|c|c|c|c|c|}
\hline & & $\mid \begin{array}{c}\text { Orig. } \\
\text { variety }\end{array}$ & $\begin{array}{l}\text { Out- } \\
\text { cross }\end{array}$ & $\begin{array}{l}\text { Sib- } \\
\text { cross }\end{array}$ & $\begin{array}{l}\text { Second } \\
\text { sib- } \\
\text { cross }\end{array}$ & $\begin{array}{l}\text { Self- } \\
\text { ing }\end{array}$ & $\begin{array}{l}\text { Change per } \\
\text { yo per cent. } \\
\text { inbreeding }\end{array}$ \\
\hline Leaf size $\left(\mathrm{mm} .{ }^{2}\right)$ & $\begin{array}{l}\text { Irish } \\
\text { Kent }\end{array}$ & $\begin{array}{r}1076 \\
84^{1}\end{array}$ & $\begin{array}{l}1056 \\
1002\end{array}$ & $\begin{array}{r}1002 \\
901\end{array}$ & $\begin{array}{l}889 \\
879\end{array}$ & $\begin{array}{l}79^{\circ} \\
464\end{array}$ & $\begin{array}{l}51 \cdot 0 \pm 17 \cdot 9^{* *} \\
48 \cdot 7 \pm 28 \cdot 5 \mathrm{~ns}\end{array}$ \\
\hline $\begin{array}{l}\text { Rate of leaf appearance } \\
\text { (days per leaf) }\end{array}$ & $\begin{array}{l}\text { Irish } \\
\text { Kent }\end{array}$ & $\begin{array}{l}7 \cdot 3 \\
7 \cdot 0\end{array}$ & $\begin{array}{l}7 \cdot 1 \\
7 \cdot 2\end{array}$ & $\begin{array}{l}7 \cdot 6 \\
7 \cdot 4\end{array}$ & $\begin{array}{l}7 \cdot 7 \\
7 \cdot 3\end{array}$ & $\begin{array}{l}7 \cdot 3 \\
7 \cdot 6\end{array}$ & $\begin{array}{l}0.003 \pm 0.093 \mathrm{~ns} \\
0.083 \pm 0.049 \mathrm{~ns}\end{array}$ \\
\hline Tiller No. & $\begin{array}{l}\text { Irish } \\
\text { Kent }\end{array}$ & $\begin{array}{l}18 \cdot 5 \\
17 \cdot 3\end{array}$ & $\begin{array}{l}19 \cdot 8 \\
15.9\end{array}$ & $\begin{array}{l}15 \cdot 6 \\
14 \cdot 6\end{array}$ & $\begin{array}{l}13.9 \\
13.3\end{array}$ & $\begin{array}{l}14 \cdot 2 \\
13 \cdot 2\end{array}$ & $\begin{array}{l}1 \cdot 20 \pm 0 \cdot 22^{* * *} \\
0 \cdot 76 \pm 0 \cdot 28^{*}\end{array}$ \\
\hline $\begin{array}{l}\text { Dry weight per plant } \\
\text { (gm.) }\end{array}$ & $\begin{array}{l}\text { Irish } \\
\text { Kent }\end{array}$ & $\begin{array}{l}0.55 \\
0.44\end{array}$ & $\begin{array}{l}0.59 \\
0.47\end{array}$ & $\begin{array}{l}0.44 \\
0.38\end{array}$ & $\begin{array}{l}0.35 \\
0.33\end{array}$ & $\begin{array}{l}0.33 \\
0.21\end{array}$ & $\begin{array}{c}0.54 \pm 0.006^{* * *} \\
0.040 \pm 0.015^{*}\end{array}$ \\
\hline $\begin{array}{l}\text { Dry weight per tiller } \\
\text { (mgm.) }\end{array}$ & $\begin{array}{l}\text { Irish } \\
\text { Kent }\end{array}$ & $\begin{array}{l}31 \cdot 0 \\
25 \cdot 5\end{array}$ & $\begin{array}{l}30 \cdot 6 \\
27 \cdot 8\end{array}$ & $\begin{array}{l}28 \cdot 3 \\
27 \cdot 3\end{array}$ & $\begin{array}{l}25 \cdot 7 \\
25 \cdot 5\end{array}$ & $\begin{array}{l}23 \cdot 8 \\
16 \cdot 0\end{array}$ & $\begin{array}{l}\mathrm{x} \cdot 36 \pm 0.476^{* *} \\
0.95 \pm 0.762 \mathrm{~ns}\end{array}$ \\
\hline No. of samples . & $\begin{array}{l}\text { Irish } \\
\text { Kent }\end{array}$ & $\begin{array}{l}2 \\
2\end{array}$ & $\begin{array}{l}8 \\
4\end{array}$ & $\begin{array}{l}8 \\
7\end{array}$ & $\begin{array}{l}6 \\
2\end{array}$ & $\begin{array}{l}6 \\
1\end{array}$ & \\
\hline $\begin{array}{l}\text { Coefficient of in- } \\
\text { breeding }\end{array}$ & & 0 & 0 & 0.25 & 0.375 & 0.50 & \\
\hline
\end{tabular}


There is no regular pattern of correlated response. Out of the 20 possible comparisons (late-early) in the fourth generation, only one (leaf size in Kent) shows a significant difference, while in the fifth generation only 3 differences (all in Irish) are significant. Furthermore, the differences are not always in the same direction. This lack of regularity is similar to that previously reported for other ear characters, such as ear length and number of spikelets (Cooper, I96o) and suggests that ear emergence and seedling characters could be selected independently.

It now remains to assess the mean inbreeding depression in the selection lines, using these seedling characters as standards. As table 7 shows, all the seedling components, except rate of leaf appearance, show inbreeding depression at a roughly linear rate. A comparison of the fourth and fifth generation selection lines with the original varieties, however, shows that in only 5 out of Io instances was a significant depression obtained in seedling characters. There was no evidence of a greater degree of inbreeding depression in the late selection lines, although these might be expected to be more homozygous. The degree of inbreeding required to produce these effects in the selection lines has been calculated, and in nearly all cases the actual degree of inbreeding is considerably less than that expected on theoretical grounds. No deliberate selection for vigour was made in the seedling stage, and any natural selection for heterozygotes must have operated before germination, either through differential fertility of the parents, or during early seed development.

It is clear, therefore, that the seedling characters, although known to show inbreeding depression, do not appear to have been greatly influenced by selection for ear emergence.

\section{DISCUSSION}

The genetic structure of these varieties of ryegrass is evidently similar to that of other outbreeding species in that most individuals are highly heterozygous and can carry much potential genetic variation. The amount of variation and its rate of release will depend on two factors, the past selection history of the character, and its relation to fitness (Robertson, A., I955).

\section{(i) Response to selection}

The pattern of short-term response for ear emergence is similar to that for other characters showing largely additive genetic variation, such as body weight and bristle number in Drosophila (Mather, I 953; Robertson, F. W., I955; Clayton, Morris and Robertson, 1957). Response is still continuing in the sixth generation and the means of the selection lines go well outside the limits of the original varieties. There are, however, regular varietal and directional differences in the pattern of response. 
The selection differential, the response and the realised heritability are much greater in Kent than in Irish for all selection lines. Irish ryegrass has been exposed to selection for uniform flowering during more than 70 generations of seed multiplication, although a range of 20-25 days is possible within any seed crop (Cooper, I959a). Kent ryegrass, on the other hand, is derived from old pastures which have been grazed for many decades, and the commercial seed is only a few generations removed from these old pastures. Apart from the effects of heavy spring grazing, there has been no selection for uniformity of flowering in the original sward, although three or four generations of seed multiplication may well have limited the phenotypic variation present. Kent ryegrass has thus been exposed in the past to less stringent selection for flowering time than Irish, which may account for its more rapid release of variation.

The other marked feature is the asymmetrical response in the late and early lines. Possible causes of such asymmetry have been discussed by Falconer (1955). In the present case, the selection differential is similar in the two directions, which leaves directional dominance (inbreeding depression) or unequal gene-frequencies as possible explanations.

Date of ear emergence shows some inbreeding depression, selfing resulting in a delay of about 6 days (Cooper, I 9596 ), so presumably some directional dominance exists. Selection would therefore be expected to progress more rapidly in the late direction, because of the selection of more homozygous plants in the late lines (Falconer, I955), although the recorded asymmetry would require a greater degree of inbreeding than appears to be present in the selection lines. There is no evidence on the relative gene frequencies in the two directions, but selection in the past has probably favoured an intermediate expression of the character.

So far no marked ceiling of response has been reached, but this would not be expected on genetical grounds as early as the sixth generation (Falconer, I 955; Clayton, Morris and Robertson, I957). Response has continued steadily in most lines, and the range between the extreme lines is now 8 to I 5 times the original phenotypic standard deviation. There is still appreciable phenotypic variation within most lines (table 4) though this does not necessarily mean that response to selection can still be expected (Robertson, F. W., I 955).

A physiological limit has, however, been reached in the extreme early line (from Irish) and in the extreme late line (from Kent). Ear initiation in Lolium in the spring is a response to long photoperiod, but further elongation and development of the inflorescence are strongly influenced by spring temperature (Cooper, I 959a). In the late Kent line, a few non-heading plants have appeared in the sixth generation, possibly because of a high photoperiod requirement. In the early Irish line, on the other hand, although the photoperiod requirement is low, the earliest plants may be initiating heads at a date when spring 
temperature is too low for any active growth. Furthermore, since ear emergence in the early lines is a complex response to temperature and photoperiod, selection in a warm spring could operate for a low critical photoperiod, but in a cold spring, temperature might be limiting, resulting in appreciable genotype-year interaction. Such interaction may explain the low realised heritability in the early selection line from Irish (table 2).

The main limit to selection so far has been low fertility and therefore attenuated selection pressure in the lines KEL and KLE. Since only 50 seedlings of each line are required in each generation to continue the selection programme, moderate infertility has not been selected against.

\section{(ii) Changes in fertility and vigour}

Selection for a single character has frequently been reported to produce associated reductions in fertility and viability (Mather and Harrison, I949; Lerner and Dempster, I95I; Clayton, Morris, Knight and Robertson, 1957) though low fertility does not usually become a problem until after i 5 to 20 generations. The usual explanation of such decline is the unbalancing effect of selection for one character on closely-linked genes controlling fertility and viability. In addition, most selection experiments involve some degree of inbreeding, which itself would be expected to unbalance fertility in a normally outbreeding population (Rees, I955).

In the present case, fertility is high in both original varieties, though less so in Kent, which has presumably undergone less stringent selection for seed production in the past. In fact, Davies (I954), in a survey of potential breeding material from old pastures found a range of i 2 per cent. to 76 per cent. with a mean of 42 per cent., suggesting little selection for seed fertility under these conditions. By the sixth generation, however, both male and female fertility have fallen markedly, usually more in Kent than in Irish, and more in the late lines than the early lines. Even so, most lines contain a range of values, and selection for high fertility should be possible.

This rapid decline in fertility may be the result either of selection or of the accompanying inbreeding, which may be quite high (the theoretical inbreeding coefficient is 0.45 by the sixth generation). The evidence from the seedling characters, however, indicates that the actual degree of inbreeding is considerably less than the theoretical, and this is also borne out by the maintenance of genotypic variation in the selection lines.

The lack of unbalance in the seedling characters suggests either that fertility is more sensitive than seedling vigour, or that some developmental (rather than strictly genetical) relationship with ear emergence is involved. Cytological analysis to be reported later shows that in the selection lines the timing of meiosis is unbalanced relative 
to ear emergence, being advanced in the late lines and retarded in the early ones.

Further work is evidently necessary to separate the effects of inbreeding from the genetical unbalance caused by selection and from the developmental unbalance resulting from abnormal timing of meiosis. The possibilities of selecting for higher fertility in these lines is also important.

\section{(iii) Plant breeding implications}

In these ryegrass varieties, rapid and extensive response to selection has been obtained for one character, date of ear emergence, without correlated change in other ear characters, or in seedling components of vigour, though with a decrease in fertility. Is such response likely to be possible for other agronomic characters, and what are the dangers of an associated decline in fertility?

As Robertson, A. (1955) points out, the pattern and extent of response to selection in a character will depend on its previous selection history and on its relation to fitness. If a character is closely related to fitness, as for egg-laying in Drosophila and probably fertility in ryegrass, selection will have favoured a maximum expression in the past, and little additive genetic variation will be left. Furthermore, if selection is relaxed the character may well decline in fitness. If, however, a character has been selected for intermediate expression, as for date of ear emergence in ryegrass and possibly body size in Drosophila, appreciable additive genetic variation may remain, although there may be some inbreeding depression. In the extreme case, where a character appears to be peripheral to fitness, as in chaeta number in Drosophila, much additive genetic variation should occur and response to selection should be rapid and extensive.

In ryegrass and other herbage grasses, therefore, one would expect immediate components of fitness, such as survival under competition in a pasture sward, or fertility in a seed crop, to have been already selected for maximum expression and show little additive genetic variation and response to selection. On the other hand, characters which do not contribute to survival in the field, such as nutritive value and certain biochemical and mineral components (Vose, 1960) may retain useful additive genetic variation, provided they possess no negative genetic correlation with fitness.

This argument may not seem at first sight to offer much hope to the plant breeder for the direct selection of major components of fitness. It must be remembered, however, that even such major components as competitive ability and seasonal pattern of growth have been selected for optimum expression in one particular environment only. There appears for instance, to have been little or no selection for seed fertility in old pastures. Transfer of the population or variety to a different environment may uncover useful additive genetic variation. As shown earlier (Cooper, 1959a), ryegrass populations which are uniform in 
flowering behaviour in their native environment may diverge greatly when transferred to others, and similarly those plants which show greatest competitive ability under intense defoliation do not necessarily produce most herbage under lenient cutting (Cooper, unpublished). Clausen and Hiesey (1958) have shown that the introduction of adapted ecotypes into other climatic environments may reveal a wealth of newly available variation, and the same may well be true for changes in agronomic management.

Work has, therefore, been started in ryegrass to assess the amount of additive genetic variation and response to selection for a number of agronomic characters, paying special attention to their past selection history, their relation to fitness and their expression in different environments (Cooper and Edwards, 196r).

\section{SUMMARY}

I. Selection for early and late ear emergence has been continued for six generations in Irish and Kent perennial ryegrass and associated changes in fertility and seedling components of vigour have been recorded.

2. Response to selection has carried all lines well outside the limits of the original varieties, and by the fourth generation the full range of Irish had been obtained from Kent and vice versa. Backselection, which was started in the first generation, indicates that much potential genetic variation can be carried within four foundation plants of similar phenotype.

3. Both the possible selection differential and the realised heritability are greater in Kent than in Irish, possibly because of less stringent agronomic selection in the past. Response was asymmetrical in both varieties, being more rapid in the late direction, perhaps in part because of inbreeding depression in the late lines.

4. Male and female fertility were high in the original varieties but had declined in all lines by the sixth generation, in some cases severely reducing the possible selection differential. The variation in fertility between plants was increased in the selection lines, giving possibilities of future selection for high fertility.

5. Although most seedling characters, such as leaf size, tiller number and dry weight, show marked inbreeding depression, there is no invariable decline in these characters during the selection programme, and the actual degree of inbreeding is rather less than that expected on theoretical grounds. There is no regular correlated response in any of the seedling characters to selection for ear emergence.

6. These results are discussed in relation to the past selection history of the varieties, and it is concluded that a similar pattern of response might be expected for other agronomic characters, which are not immediate components of fitness. 
Acknowledgments.--It is a pleasure to acknowledge the facilities provided and interest taken in this work by Professor P. T. Thomas, Director of the Welsh Plant Breeding Station. I am grateful to Mr A. R. Beddows, Dr M. Borrill and Dr E. L. Breese of the Grass Breeding Section of the Station for helpful discussion, and to Miss Irene D. Rees for editing the manuscript.

\section{REFERENCES}

CLAUSEN, J., AND HIESEY, W. M. 1958. Experimental studies on the nature of species. IV. Genetic structure of ecological races. Carnegie Inst. Wash. Pub., 6I5, pp. 3 I 2. CLAYTON, G. A., MORRIS, J. A., AND ROBERTSON, A. 1957. An experimental check on quantitative genetical theory. I. Short-term responses to selection. $\mathcal{J}$. Genet., 55, 131-15I.

CLAYTON, G. A., MORRIS, J. A., KNIGHT, G. R., AND ROBERTSON, A. I957. An experimental check on quantitative genetical theory. III. Correlated responses. 7. Genet., 55, I 7 I-180.

COOPER, J. P. I959a. Selection and population structure in Lolium. I. The initial populations. Heredity, I3, 31 7-340.

COOPER, J. P. I $959 b$. Selection and population structure in Lolium. II. Genetic control of date of ear emergence. Heredity, 13, 445-459.

COOPER, J. P. 1959c. Selection and population structure in Lolium. III. Selection for date of ear emergence. Heredity, $13,46 \mathrm{r}-479$.

COOPER, J. P. I96o. Selection and population structure in Lolium. IV. Correlated response to selection. Heredity, ${ }_{4} 4,229-246$.

COOPER, J. P., AND EDWARDS, K. J. R. I96 I. The genetic control of leaf development in Lolium. I. Assessment of genetic variation. Heredity, 16, 63-82.

DAVIES, W. E. 1954. " Shift" in a late-flowering strain of perennial ryegrass (Lolium perenne). Proc. Europ. Grassl. Congr., O.E.E.C. Paris. I02-106.

FALCONER, D. s. 1955. Patterns of response in selection experiments with mice. Cold Spr. Harb. Symp. Quant. Biol., 20, 178-196.

LERNER, I. M., AND DEMPSTER, E. M. I95I. Attenuation of genetic progress under continued selection in poultry. Heredity, 5, 75-94.

Mather, x. 1953. The genetical structure of populations. Symp. Soc. expt. Biol., $7,66-95$.

mather, K., AND harrison, B. J. I949. The manifold effect of selection. Heredity, 3, I-52, I 3 I-I 62 .

REES, H. I 955. Heterosis in chromosome behaviour. Proc. Roy. Soc. B., I44, I 50-I 59. Robertson, A. 1955. Selection in animals; synthesis. Cold Spr. Harb. Symp. Quant. Biol., 20, 225-229.

ROBERTSON, F. W. I955. Selection response and the properties of genetic variation. Cold Spr. Harb. Symp. Quant. Biol., 20, I66-I 77.

vose, P. B. Ig6o. Intraspecific differences in nutrient uptake and assimilation. Ann. Rep. Welsh Pl. Breed. Sta., 1959, 18-20. 